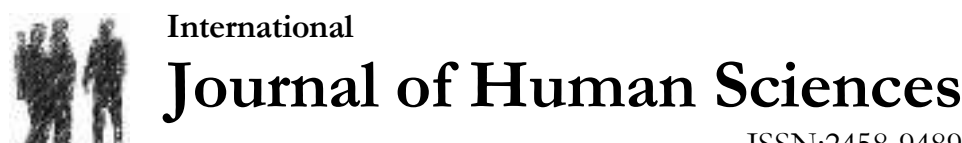 \\ ISSN:2458-9489
}

Volume 14 Issue 4 Year: 2017

\section{Evaluation of physical and physiological parameters of the elite underwater rugby players}

\author{
Osman Ates ${ }^{1}$ \\ Levent Cavas ${ }^{2}$ \\ Isa Sagiroglu ${ }^{3}$ \\ Celal Gencoglu ${ }^{4}$ \\ Cem Seref Bediz ${ }^{5}$
}

\begin{abstract}
Underwater rugby (UWR) is a developing sport which is organised under umbrella of Confédération Mondiale des Activités Subaquatiques. Although this sports has over than 50 years history, very few studies have so far been published in the sports literature. This research reveals physical and physiological profiles of UWR players in Turkey. Eleven male athletes participated to this study. Their body weight, height, body fat proportion, skinfold thicknesses, length and girth measurements, strength, flexibility, respiratory functions, anaerobic capacities, aerobic capacities were measured. In pool tests, $50 \mathrm{~m}$ crawl style, $50 \mathrm{~m}$ apnea, $8 \times 25 \mathrm{~m}$ apnea and $400 \mathrm{~m}$ crawl style with UWR equipments were done. Body mass index, body fat proportion, skinfold thickness of the underwater rugby players were higher compared to swimming and water polo literature. A positive correlation was found both between the $50 \mathrm{~m}$ apnea times and body fat proportions of the players and also among the $400 \mathrm{~m}$ crawl style with $\mathrm{ABC}$ equipments and body fat proportions and body weights of the players. A significant positive correlation was detected among skinfold thickness and the $50 \mathrm{~m}$ crawl style times with UWR equipments, $50 \mathrm{~m}$ apnea times, $8 \times 25 \mathrm{~m}$ apnea times and $400 \mathrm{~m}$ crawl style times. Pulmonary volumes and capacities of the athletes were found higher than those of the water polo players and swimmers. This increase in the work of breathing muscles might be caused by hyperventilation of the underwater players before and after breathholding and blowing out the water in the snorkel after diving. In conclusion, more comparative data from UWR players is strongly warranted to define the physical and physiological features of UWR players.
\end{abstract}

Keywords: Underwater rugby, Anthropometry, Swimming, Anaerobic Test, Aerobic Capacity

\footnotetext{
${ }^{1}$ Assist. Prof, Istanbul University, Faculty of Sports Sciences, Department of Coaching Education, osman-ates@hotmail.com

2 Prof. Dr., Dokuz Eylül University, Faculty of Sciences, Department of Chemistry, levent cavas@yahoo.com. Confédération Mondiale des Activités Subaquatiques (CMAS), Underwater Rugby Commission.

3 Assist. Prof, Trakya University, School of Kirkpinar Physical Education and Sports, Department of Coaching Education, isasagiroglu@,trakya.edu.tr

${ }^{4}$ Dr, Dokuz Eylül University, School of Sport Sciences and Technology, celogenc@yahoo.com

${ }^{5}$ Prof. Dr., Dokuz Eylül University, Faculty of Medicine, Department of Physiology, cem.bediz@,deu.edu.tr
} 
Ates, O., Cavas, L., Sagiroglu, İ., Gencoglu, C, \& Bediz, C. S. (2017). Evaluation of physical and physiological parameters of the elite underwater rugby players. Journal of Human Sciences, 14(4), 3940-3950. doi: $10.14687 /$ ihs.v14i4.4728

\section{Introduction}

Having specific body size undoubtably gives great advantage in terms of skills (Svantesson et al. 2008), Frenkl et al. 2001). Around the world, in studies dealing with anthropometric features around the world, the most highly debated issues include which body profiles are more suitable for which branches and the importance degree of this feature in terms of aptitude eliminations for underwater sports (Svantesson et al. 2008), Sogut et al. 2004). Anthropometric features have a crucial role in determining the success potential by giving specific information about growth and development, body composition, nutritional status, body shapes, proportionality (Dahjio et al. 2016, Nekooei et al. 2016). Thorough understanding of the athletes' physical and physiological features contributes primarily to the activities in terms of training science; that is to say, it bears crucial importance for team trainers, coaches and exercise scientists in determining better training conditions and more suitable programs (Ostojic, 2000). Enabling the best development of athletes' physiological capacity and physical skills (Koc, 2006).

There is some difficulty in proposing evaluating tests. Such tests should evaluate the physio-metabolic characteristics of the athletes as well as the athletic conditioning (specific training) and aspects of the typical technical abilities of the sport (Melchiorri et al. 2010).

Underwater rugby (UWR) is a three dimensional sport that is played inside a pool with the width of 8-12 m, the length of 12-22 $\mathrm{m}$ and the depth of 3.5-5.0 m. It is played with a ball filled with salty water with the circumferences for men and women are $520-540 \mathrm{~mm}$ and $490-510 \mathrm{~mm}$, respectively. A team consists of 15 players, 6 of them being active and the other 6 being substitute players. The rest of 3 players are known as reserve players and these players can be substituted during the game based on trainer's request and approval of referees. The goals, with the height of $445-455 \mathrm{~mm}$ and diameter of $390-400 \mathrm{~mm}$, are placed at the end of each team's field in the bottom of the pool (Cmas Underwater Rugby Fame Rules). The aim of the game is to score goals by shooting the ball into the opponents' goal. The underwater rugby players use masks, fins and snorkels. The masks of UWR players are different compared to classical masks in terms of conjunctions parts. Since the sports is a combat sport, the mask should be tightly fitted to the face to prevent leakage of water. The game is composed of two halves, each lasting for 15 minutes with an interval for 5 minutes between halves. First International UWR Championships were organised in Malmö, Sweden during 28-30 May 1978 by Confédération Mondiale des Activités Subaquatiques (CMAS). Today, this sports is actively played in 26 countries and the number is increasing thanks to social media. UWR is very enjoyable physical exercise and it could be considered as an alternative exercise to combat with obesity and also diabetes. UWR activities in Turkey started in 1992 with Turkish Championships. According to latest Turkish championships (The Turkish Federation Cup, 26-29 January 2017, Izmir-Turkey), 12 men and 7 women teams are active in UWR. To the best of our knowledge, Turkey has maximum team numbers in UWR among UWR playing countries. No published materials on the evaluation of physical and physiological profiles of UWR players has so far been published in the scientific literature. There was a great gap for the identification of sportbased characteristics of UWR players. To fulfill this need, the objective of this study is to determine the profiles of UWR players by identifying specific physical and physiological features of elite athletes who participates in regular UWR trainings. 
Ates, O., Cavas, L., Sagiroglu, İ., Gencoglu, C, \& Bediz, C. S. (2017). Evaluation of physical and physiological parameters of the elite underwater rugby players. Journal of Human Sciences, 14(4), 3940-3950. doi: $10.14687 /$ ihs.v14i4.4728

\section{Method}

\section{Subjects}

Eleven male young-senior elite underwater rugby players (age:25.5 \pm 5 years, sport age: $8.7 \pm 3.3$ years) participated to this study. Six of UWR players were member of Turkish National UWR Team. The rest of the players were also experienced and well-qualified UWR players. All players gave a written consent upon having been informed about the objective and methods of the study.

\section{Physical Measurements}

All players were measured in height, weight and body fat percentage before the actual tests. While measuring height and weight, the players removed their shoes and were simply wearing shorts. For the height measurements, a metal meter fixed on the wall was used. The weight and body fat percentage were measured with a Tanita brand mark, BF 556 model impedance device.

In order to determine regional fatness of the players, the measurements were recorded from triceps, suprailiac area, calf and abdominal by using caliper skinfold. Furthermore, chests, chests at the inspiration, femoral, biceps at external, perimeters of the forearm and bust, arm length, hand and total leg length were measured with a tape. Additionally, the strength tests of the athletes were executed with hand, back and leg dynamometer and the flexibility rates were determined with the sit and reach table.

\section{Strength assessments}

Measurement of handgrip strength

The strengths of the forearm and hand flexors of the athletes were measured with a Takei (Japan trademark) brand mark, hand dynamometer and the measurements were recorded for both right and left hand. The best results were recorded in kilograms.

Measurement of back and leg strength

The tests were carried out with the Takei (Japan) brand mark back and leg dynamometer. The best results of three experiment tests were recorded in kilograms.

Measurement of abdominal strength

Each athlete was placed in a lying back position with their knees flexed at a 90 degrees angles. Next, each subject straightened up from his back, touched his knees and lied back, this was considered as a single movement. The number of total sit ups in one minute was recorded.

\section{Sit and Reach Flexibility Test}

The flexibility rates of the athletes were determined on a sit and lie table. The extent was measured in centimetres upon the subjects' waiting for 1-2 seconds at the furthest point of the table.

\section{Physiological Measurements \\ Respiratory Function Test}

The vital capacity (VC), forced vital capacity (FVC), forced expiratory volume in first second $\left(\mathrm{FEV}_{1}\right)$ and maximum voluntary ventilation $(\mathrm{MVV})$ values were determined by evaluating lungs volume and capacities with a Spirobank brand mark spirometer.

\section{Anaerobic Power Test}

In order to determine anaerobic power of the athletes, the known valid and authentic vertical jumping and Wingate test were applied. The vertical jumping test was carried out with a Takei (Japan) brand mark jump meter and Wingate anaerobic test was carried out with a Monark 839E bicycle ergometer. The Wingate test was conducted by applying a weight of approximately 75 gr per body weight of the athletes. Besides the estimated average and peak strength, the heart rate at the end of the test was also recorded with a Polar XTrainer Plus brand mark heart rate monitor. 
Ates, O., Cavas, L., Sagiroglu, İ., Gencoglu, C, \& Bediz, C. S. (2017). Evaluation of physical and physiological parameters of the elite underwater rugby players. Journal of Human Sciences, 14(4), 3940-3950. doi: $10.14687 /$ ihs.v14i4.4728

\section{Aerobic Capacity Test}

In order to determine the aerobic capacity of the athletes, it was measured directly against gradually increasing load. Monark brand mark 839E model bicycle ergometer, Biopac Brand mark MP100 model (Santa Barbara, California) metabolic analyser system and Polar XTrainer Plus brand mark heart rate monitor were used for the measurements. After the warm up period of 5 minutes pedalling against $50 \mathrm{watt}$ weight, the test with 100 watt weight was started. The weight was increased by 25 watt in each 2 minutes and the weight increments were continued until exhaustion. Tests were considered maximal when at least three of the following criteria were observed: plateau in $\mathrm{HR}_{\max }>90 \%$ of predicted value for age (220 - age), concept of Perceived Effort $\geq 18$, RER (respiratory exchange rate) $\geq 1.15$, and maximal voluntary fatigue with inability to maintain the preestablished rhythm. $\mathrm{VO}_{2 \max }$ was determined as the highest value found at the end of the test. Gas mixture was balanced and gas flow was calibrated (Nogueira, 2006).

\section{Specific Tests related to the UWR}

The pool tests considered to be related to the sport were realized at in an indoor swimming pool with a $25 \mathrm{~m}$ in length. The athletes used masks, fins and snorkels (during the tests). At the end of the test their test end heart rates were measured with a polar band leaned on the chest after the athlete came out of the pool.

\section{$50 \mathrm{~m}$ Crawl Style with UWR Equipment}

The athletes were asked to complete $50 \mathrm{~m}$ surface swimming at the shortest possible time. At the end of the 50 meters, finishing times and heart rates were recorded.

\section{$50 \mathrm{~m}$ Apnea Test}

The athletes were asked to complete $50 \mathrm{~m}$ underwater swimming at the shortest possible time. At the end of the 50 meters, finishing times and heart rates were recorded.

\section{8x25 Underwater Swimming Lactate Test}

The athletes were asked to swim under the water for 25 meters and the chronometers were started at the start time. Athletes were let to surface in each after every 25 meters and additionally the waiting time at the each ends of the pool was decided to be up to the athletes. (After every 25 meters they were allowed to surface, however, the duration of waiting time at the each ends of the pool was up to the athletes to decide themselves). The chronometer continued until total $200 \mathrm{~m}$ was completed by athletes. With this procedure, athletes were made to swim from $8 \times 25 \mathrm{~m}$ depth and at the end of the test their finishing times and heart rates were evaluated recorded. At the same time, upon the completion of the test, one drop of blood was taken to the pipette from the finger tip and lactate analysis of the blood was carried out.

\section{$400 \mathrm{~m}$ Crawl Style with UWR Equipment}

The athletes were told to complete 400 meters Crawl Style with UWR equipment at the shortest possible time. At the end of the 400 meters, finishing times and heart rates were registered.

Data Analysis: Statistical processing was done by means of the Statistical Package for the Social Sciences ${ }^{\circledR}$ package (SPSS,USA) version 13.0 and Microsoft Excel ${ }^{\circledR}$ for Windows XP® (USA). Descriptive statistics were used with means \pm standard deviations (SD). Relations among data were analysed with Spearman Correlation Test. Data do not show normal distribution. $\mathrm{P}<0.05$ was used as the accepted level of significance. 
Ates, O., Cavas, L., Sagiroglu, İ., Gencoglu, C, \& Bediz, C. S. (2017). Evaluation of physical and physiological parameters of the elite underwater rugby players. Journal of Human Sciences, 14(4), 3940-3950. doi: $10.14687 /$ ihs.v14i4.4728

\section{Findings}

\section{Physical Measurements}

Ages, sport ages, body weights $(\mathrm{BW})$, heights $(\mathrm{H})$, body mass index (BMI), body fat rate (BFR) characteristics of the UWR players are shown in Table 1.

BW was positively correlated to $400 \mathrm{~m}$ meters crawl swimming time $(\mathrm{r}=0.71, \mathrm{P}=0.03)$ and besides BFR was found to be positively correlated to times at $50 \mathrm{~m}$ apnea and $400 \mathrm{~m}$ meters crawl swimming time $(\mathrm{r}=0.71, \mathrm{P}=0.03 ; \mathrm{r}=0.73, \mathrm{P}=0.02)$. Furthermore, the athletes' heights were significantly positively correlated to $\mathrm{VC}$ values and $\mathrm{FVC}$ values in this study $(\mathrm{r}=0.67, \mathrm{P}=0.02$ and $\mathrm{r}=0.78, \mathrm{P}=0.005)$.

Table 1. Age, Sport age (years), H, BW, BMI and BFR Values

\begin{tabular}{ccccccc}
\hline $\mathrm{n}=11$ & $\begin{array}{c}\text { Age } \\
\text { (years) }\end{array}$ & Sport Age (years) & BW $(\mathrm{kg})$ & $\mathrm{H} \mathrm{cm})$ & BMI & BFR (\%) \\
Average & 23.5 & 8.7 & 89.3 & 182.3 & 27.0 & 19.7 \\
SD & 4.4 & 3.3 & 11.8 & 4.8 & 4.1 & 6.2 \\
\hline
\end{tabular}

Skinfold thickness of the underwater rugby players are shown in Table 2. Abdominal skinfold thickness was significantly positively correlated to $50 \mathrm{~m}$ meters crawl swimming, $50 \mathrm{~m}$ apnea, 8x 25 $\mathrm{m}$ apnea, $400 \mathrm{~m}$ meters crawl swimming times $(\mathrm{r}=0.66, \mathrm{P}=0.05 ; \mathrm{r}=0.71, \mathrm{P}=0.03 ; \mathrm{r}=0.73, \mathrm{P}=0.02$; $\mathrm{r}=0.75, \mathrm{P}=0.02)$ and suprailiac skinfold thickness was also significantly positively correlated to $50 \mathrm{~m}$ crawl swimming, $50 \mathrm{~m}$ apnea, $8 \times 25 \mathrm{~m}$ underwater swimming, $400 \mathrm{~m}$ surface swimming times $(\mathrm{r}=0.75, \mathrm{P}=0.02 ; \mathrm{r}=0.83, \mathrm{P}=0.006 ; \mathrm{r}=0.76, \mathrm{P}=0.01 ; \mathrm{r}=0.86, \mathrm{P}=0.002)$.

Table 2. Skinfold Measurement Values

$\mathrm{n}=11 \quad$ Triceps $(\mathrm{mm}) \quad$ Suprailiac $(\mathrm{mm}) \quad$ Abdominal $(\mathrm{mm}) \quad$ Calf $(\mathrm{mm})$
Average
12.4
15.0
23.0
13.5
SD
2.9
6.1
7.4
4.5

Peripheral and height measurements of the underwater rugby players are shown in Table 3 . Bust lengths of the athletes were significantly positively correlated to $8 \times 25 \mathrm{~m}$ underwater swimming times $(r=-0.68, P=0.04)$. At the same time, bust lengths of the athletes were also positively correlated to $\mathrm{VC}$ values $(\mathrm{r}=0.65, \mathrm{P}=0.02)$ and $\mathrm{FVC}$ values $(\mathrm{r}=0.70, \mathrm{P}=0.01)$.

Table 3. Peripheral and Height Measurement Values

\begin{tabular}{cccccccccc}
\hline $\mathrm{n}=11$ & $\begin{array}{c}\text { Chest } \\
\text { girth }(\mathrm{cm})\end{array}$ & $\begin{array}{c}\text { Chest at } \\
\text { inspiration } \\
(\mathrm{cm})\end{array}$ & $\begin{array}{c}\text { Thigh } \\
\text { girth } \\
(\mathrm{cm})\end{array}$ & $\begin{array}{c}\text { Ex. } \\
\text { Biceps } \\
(\mathrm{cm})\end{array}$ & $\begin{array}{c}\text { Bust } \\
\text { lgth. } \\
(\mathrm{cm})\end{array}$ & $\begin{array}{l}\text { Arm } \\
(\mathrm{cm})\end{array}$ & $\begin{array}{c}\text { Hand } \\
\text { lgth. } \\
(\mathrm{cm})\end{array}$ & $\begin{array}{c}\text { Total } \\
\text { Length } \\
(\mathrm{cm})\end{array}$ & $\begin{array}{c}\text { Forearm } \\
(\mathrm{cm})\end{array}$ \\
$\begin{array}{ccccccc}\text { Average } \\
\text { SD }\end{array}$ & 105.2 & 109.2 & 62.8 & 32.4 & 95.9 & 62.8 & 18.8 & 94.8 & 28.8 \\
\hline
\end{tabular}


Ates, O., Cavas, L., Sagiroglu, İ., Gencoglu, C, \& Bediz, C. S. (2017). Evaluation of physical and physiological parameters of the elite underwater rugby players. Journal of Human Sciences, 14(4), 3940-3950. doi: $10.14687 /$ ihs.v14i4.4728

The strength test results and the flexibility values of the underwater rugby players are shown in Table 4. There found no expected negative correlation between strength measurements and swimming times of the athletes. The number of sit up for abdominal strength was significantly positively correlated to $\mathrm{VO}_{2 \max }(\mathrm{r}=0.66, \mathrm{P}=0.02)$.

Table 4. Strength Tests, Flexibility Measurement Values

\begin{tabular}{ccccccc}
$\mathrm{n}=11$ & $\begin{array}{c}\text { Right Hand } \\
(\mathrm{kg})\end{array}$ & $\begin{array}{c}\text { Left Hand } \\
(\mathrm{kg})\end{array}$ & $\begin{array}{c}\text { Back } \\
(\mathrm{kg})\end{array}$ & $\begin{array}{c}\text { Leg } \\
(\mathrm{kg})\end{array}$ & $\begin{array}{c}\text { Abdominal } \\
\text { Strength }\end{array}$ & $\begin{array}{c}\text { Flexibility } \\
(\mathrm{cm})\end{array}$ \\
$\begin{array}{c}\text { Average } \\
\text { SD }\end{array}$ & 50.1 & 47.3 & 161.3 & 193.1 & 63.8 & 11.3 \\
\hline
\end{tabular}

The Wingate test results and vertical jumping values that were carried on to determine anaerobic capacities of the athletes are shown in Table 5. There was no significant positive correlation between Wingate test results and vertical jumping extents.

Table 5. Wingate and Vertical Jump Test Values

\begin{tabular}{ccccc}
\hline $\mathrm{n}=11$ & $\begin{array}{c}\text { Average Strength } \\
\text { (watt) }\end{array}$ & $\begin{array}{c}\text { Peak } \\
\text { Strength } \\
\text { (watt) }\end{array}$ & $\begin{array}{c}\text { HR } \\
\text { (beat / min) }\end{array}$ & $\begin{array}{c}\text { Vertical Jump } \\
(\mathrm{cm})\end{array}$ \\
$\begin{array}{c}\text { Average } \\
\text { SD }\end{array}$ & 623.4 & 900.4 & 173.9 & 56.54 \\
\hline
\end{tabular}

$\mathrm{VO}_{2 \max }$ test end heart rates and lung volumes and capacities of the underwater rugby players are shown in Table 6.

Table 6. $\mathrm{VO}_{2 \max }, \mathrm{HR}_{\text {max }}$ And Respiratory Function Test Results

\begin{tabular}{ccccccc}
$\mathrm{n}=11$ & $\begin{array}{c}\mathrm{VO}_{2} \mathrm{max} \\
(\mathrm{ml} / \mathrm{kg} / \mathrm{min})\end{array}$ & $\begin{array}{c}\mathrm{HR} \\
(\text { beat } / \mathrm{min})\end{array}$ & $\begin{array}{c}\mathrm{VC} \\
(\mathrm{L})\end{array}$ & $\begin{array}{c}\mathrm{FVC} \\
(\mathrm{L})\end{array}$ & $\begin{array}{c}\mathrm{FEV}_{1} \\
(\mathrm{~L})\end{array}$ & $\begin{array}{c}\mathrm{MVV} \\
(\mathrm{L} / \mathrm{min})\end{array}$ \\
$\begin{array}{ccccc}\text { Average } \\
\text { SD }\end{array}$ & 52.7 & 182.9 & 6.77 & 6.62 & 5.12 & 204.65 \\
& 9.49 & 7,76 & 0.78 & 0.7 & 0.57 & 20.41 \\
\hline
\end{tabular}

$50 \mathrm{~m}$ apnea, $50 \mathrm{~m}$ and 400 crawl swimming times and heart rates at the end of the swim and 8x25 $\mathrm{m}$ apnea times and heart rates at the end of the swimming and blood lactate values at the end of swim are shown in Table $7.50 \mathrm{~m}$ crawl style with $\mathrm{ABC}$ equipment time was positively correlated to $50 \mathrm{~m}$ apnea time $(\mathrm{r}=0.71, \mathrm{P}=0.03)$.

Table 7. Swimming Times, Heart Rates and Lactate Values

$\underline{50 \mathrm{~m}}$ Crawl Swimming

$\underline{50 \mathrm{~m} \text { apnea }}$

$\mathrm{n}=9$

Time

HR

Time

HR Time

(second)

(beat $/ \mathrm{min}$

(second

(beat/min)

(min)

28.1

164.6

3.69

2.3

Av.
SD

14.5

9.1

0.4 $\underline{8 \times 25 \text { apnea }}$

HR Lv Time

(beat/min) (mmol (min)

$400 \mathrm{~m}$ Crawl

swimming

170.4

$12.07 \quad 5.52$

9.2

$\begin{array}{ll}2.3 & 0.7\end{array}$

$\begin{array}{ll}2.3 & 0.7\end{array}$

HR

(beat/min)

172.3 
Ates, O., Cavas, L., Sagiroglu, İ., Gencoglu, C, \& Bediz, C. S. (2017). Evaluation of physical and physiological parameters of the elite underwater rugby players. Journal of Human Sciences, 14(4), 3940-3950. doi:10.14687/jhs.v14i4.4728

\section{Discussion and Conclusions}

\section{Physical Measurements}

Although UWR has over than 50 years history, UWR-based scientific publications has remained very limited in the scientific literature. Because of this problem, it was very difficult to compare the results obtained from this study with the literature. Therefore, the results of this study were compared with the studies related to mainly swimming and water polo. Water polo is also played with a ball in the pool and requiring a great performance like UWR. In a study Andreoli, (2004) assessed the body composition of professional Italian water polo players who were $21 \pm 4.3$ years old, with the average height of $183.2 \pm 0.05$ and average body weight of $80.1 \pm 7.1$. In this study we reached the conclusions that average age of UWR players is $23.5 \pm 4.4$, training times (together with their swimming times) $8.7 \pm 3.3$ years, average height is $182.3 \pm 4.7 \mathrm{~cm}$, and average body weight $89.3 \pm 11.7 \mathrm{~kg}$. Lozovina and Pavicic (2004) found that the age range of the Croatian elite water polo players at the time of measurement was $21.2 \pm 4.0$ years and $21.8 \pm 3.8$ years, the height range $185.8 \pm 5.2 \mathrm{~cm}$ and $189.5 \pm 5.2 \mathrm{~cm}$, the average body weight was $85.2 \pm 7.3 \mathrm{~kg}$ and $85.9 \pm 6.9 \mathrm{~kg}$. According to these results, we can conclude that ages and average heights of the athletes resemble those of the Turkish water polo players and of athletes of other nationalities. As to their body weights, it can be said that the results are higher than those of Turkish water polo players, but close to those of athletes of other nationalities. Average BMI value of the UWR players was found to be $26.9 \pm 4.1$, and average body fat rate was found to be $\% 19.7 \pm 6.2$ with bioelectric impedance

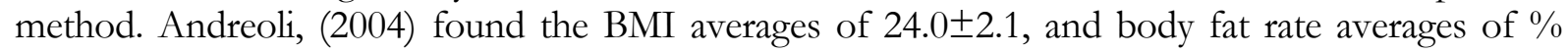
$25.8 \pm 0.3, \% 24.1 \pm 2.9$ respectively with bioelectric impedance method and skinfold caliper in water polo players. Lazovina and Pavicic (2004) found the BMI averages of Croatian elite water polo players in 1980's and 1995's generations as $24.7 \pm 1.7$ and $23.9 \pm 1.4$. The body fat rate averages were

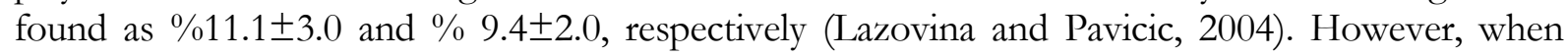
Croatian elite water polo players were compared with those of UWR players, it was realized that the values for UWR players were higher. This can be explained by the different training conditions of the players. It was found that skinfold thickness of UWR players were higher than those in other studies. C.akic1 et al (2006) measured the skinfold values of triceps, s.iliac, abdominal and calf as $10.4 \pm 3.1,16.6 \pm 6.7,20.1 \pm 9$ and $14.3 \pm 4.7$, respectively. In a water polo based study from Turkey, Turan (1989) found these values as $10.3 \pm 3,8.4 \pm 4,14.3 \pm 4.7$ and $10 \pm 3.5$, respectively. Cavas et al (2004) found triceps and abdominal skin fold values as $9.6 \pm 2.4$ and $12.9 \pm 3.1$, respectively. Lazovina and Pavicic (2004) compared the Crotian elit water polo players from two generations. They reported triceps, abdominal and calf skin folds values for 1980 and 1995's generations as $9.3 \pm 2.8-8.2 \pm 2.7 ; 13.4 \pm 5.6-10.6 \pm 4.5$ and $8 \pm 2.2-10.6 \pm 3.1$, respectively. The results of Turkish UWR players were given in Table 2 . There are some differences among the values reported in our study and also values reported in the literature. It could be said that the differences might have been caused by athletes' training conditions; another cause may have been branch differences. Suprailiac skinfold thicknesses of UWR players were significantly positively correlated to $50 \mathrm{~m}$ crawl swimming $(\mathrm{r}=0.75, \mathrm{P}=0.02), 50 \mathrm{~m}$ apnea $(\mathrm{r}=0.83, \mathrm{P}=0.006), 8 \times 25 \mathrm{~m}$ apnea times $(\mathrm{r}=0.76, \mathrm{P}=0.01)$, $400 \mathrm{~m}$ crawl swimming times $(\mathrm{r}=0.86, \mathrm{P}=0.002)$. At the same time abdominal skinfold thickness of the players were significantly positively correlated to $50 \mathrm{~m}$ crawl swimming $(\mathrm{r}=0.66, \mathrm{P}=0.05), 50 \mathrm{~m}$ apnea $(\mathrm{r}=0.71, \mathrm{P}=0.03), 8 \times 25 \mathrm{~m}$ apnea $(\mathrm{r}=0.73, \mathrm{P}=0.02), 400 \mathrm{~m}$ crawl swimming times $(\mathrm{r}=0.75$, $\mathrm{P}=0.02$ ). To summarize we can conclude that outgrowth of skinfold thicknesses at the suprailiac and abdominal parts affects swimming performance adversely.

The girth of the athletes were also measured in this study. It was found that chest girth rates and chest girth rates at inspiration in UWR players were higher than those of Turkish national water polo players (Andreoli et al. (2004). Crotian water polo players (Lazovina and Pavicic. (2004), and Turkish monofin swimmers (Alemdar, 2007). The reason of these results may be due to the increase in vital capacity, inspiration against water resistance and excessive working of ribcage of 
Ates, O., Cavas, L., Sagiroglu, İ., Gencoglu, C, \& Bediz, C. S. (2017). Evaluation of physical and physiological parameters of the elite underwater rugby players. Journal of Human Sciences, 14(4), 3940-3950. doi:10.14687/ihs.v14i4.4728

the athletes with the hyperventilation upon hypoxia during diving compared to other athletes of different branches. It has been realized that thigh girth rates of the UWR players were more higher when compared to those that were found at Turkish National Swimmers (Alemdar, 2007) and Croatian Water polo players (Lazovina and Pavicic. 2004) studies. This result may be due to fins used by UWR players. When the related studies were evaluated, it was concluded that athletes' biceps values were close to each other and these values were also found to be close to the results of this study. This may be because of the fact that biceps muscles at all branches were used at the equal level with the arm lift after leg stretching phase during swimming, at he common part of all pool sports. Forearm girth measurement values of Croatian National water polo players study were found to be close to the values of forearm girth measurement of underwater rugby players in this study (Lazovina and Pavicic. 2004). Both branches use a small ball that can be grasped by hand and for the effective control of the ball, athletes need to have strong fingers and forearms. The close value results may be due to the said reason of working of forearm muscles. We can suggest that in order to increase their control over ball, adding actions aimed at strengthening their forearms to their force strengthening trainings is beneficial both for the underwater rugby players and for water polo players. Length measurements of UWR players are also compared in this study. It was found that bust length values of Turkish National swimmers and monofin swimmers (Alemdar, 2007) were close to those of UWR players. Total leg length values of Turan's (Turan, 1989) and Aleksandrovic's (Aleksandrovic et al. (2007) studies with water polo players were close to those of UWR players in this study. Decrease in swimming time of the athletes is probably due to the fact that athletes have high bust and leg length values as UWR players generally submerge to sprint by dolphin leg stroke. Furthermore, it was found that athletes' bust length was significantly negatively correlated to $8 \times 25 \mathrm{~m}$ apnea times $(\mathrm{r}=-0.68, \mathrm{P}=0.04)$, and this finding highly supports above mentioned hypothesis. Stroke lengths of Turkish National water polo players (Turan, 1989), Turkish national swimmers and monofin swimmers (Alemdar, 2007) and young water polo players (Aleksandrovic et al. (2007) were found to be similar to the subjects of this study. Long arms and legs help UWR players to cover long distances at the first move. Furthermore, long arms also help the players catch the ball more easily under the water.

\section{Strength and Flexibility Assessments}

The strength of the right and left hand of the athletes was respectively found as $50.1 \pm 3 \mathrm{~kg}$ and $47.3 \pm 4.3 \mathrm{~kg}$. A study found right hand strength, and left hand strength of young national water polo players respectively as $41.0 \pm 9 \mathrm{~kg}$ and $37.5 \pm 5.3 \mathrm{~kg}$ (Ongun et al. 2006). Hand grip strength of UWR players were found to be higher than those of water polo players playing with the ball in the water. Furthermore, in this study back strengths, leg strengths of the players were determined respectively as $161.3 \pm 19.6 \mathrm{~kg}$ and $193.1 \pm 46.9 \mathrm{~kg}$, and sit up number in a minute was found to be 63.7 \pm 8.9 . When it was intended to compare the results with previous studies, no study was found determining these parameters in swimmers and water polo players. In UWR, athletes dive into the water in a sit up position by using their back and abdominal muscles at the surface of the water. Realizing the diving process fast and quickly is a necessary qualification for the UWR players and therefore, actions that are aimed at strengthening back and abdominal strength should be added to strength trainings. Previous studies proved that strong swimmers swim faster. In this study, there occurred no significant positive correlation between leg strengths and swim times of the players. This is possibly due to the fact that swim times of UWR players are to be mostly determined by their technical actions instead of strength. However, the strength training based upon a good knowledge of surface and underwater technical swimming skill both causes an increase at the muscle strength and at the movement speed, and thus they may probably make a positive effect on swimming time. Flexibility value averages of the players at the sit and lie table was found to be $11.3 \pm 6.4 \mathrm{~cm}$. Alemdar, (2007) determined the flexibility value averages of the swimmers as $37.9 \pm 2.9 \mathrm{~cm}$, and flexibility value averages of the swimmers with flippers as $37.3 \pm 2.7 \mathrm{~cm}$. Flexibility 
Ates, O., Cavas, L., Sagiroglu, İ., Gencoglu, C, \& Bediz, C. S. (2017). Evaluation of physical and physiological parameters of the elite underwater rugby players. Journal of Human Sciences, 14(4), 3940-3950. doi:10.14687/jhs.v14i4.4728

rates of the underwater rugby players were found to be relatively lower than the rates of swimmers and swimmers with flippers. This is probably because of the fact that more importance is given at flexibility exercise before and after training.

\section{Physiological Measurements \\ Respiratory Function Test}

When the studies in literature were evaluated, it was concluded that Delapille et al (2002), in their study with the divers found the FVC and $\mathrm{FEV}_{1}$ values of the athletes, respectively as $5.3 \pm 0.7$ liters and 4.2 \pm 0.5 liters. Turan, (1989) found the VC, FVC and FEV 1 values of the Turkish Elite water polo players, respectively as $5.2 \pm 0.4$ liters, $5.5 \pm 0.6$ liters and $4.7 \pm 0.5$ liters. In other study Wylegala, (2007) found the FVC, FEV1 and MVV values of divers, respectively $4.9 \pm 0.4$ liters, $4.7 \pm 0.5$ liters and 191.3 \pm 22.1 liters. In this study, we have found the VC, FVC, FEV ${ }_{1}$ and MVV values of the underwater rugby players, respectively as $6.7 \pm 0.7$ liters, $6.6 \pm 0.7$ liters, $5.1 \pm 0.5$ liters and $204.6 \pm 20.4$ liters/min. From the results mentioned above, we can conclude that lung volume and capacities of underwater rugby players were in a relatively higher level when compared to other previously evaluated studies. It is a well-known fact that increases in the hydrostatic pressure depending on the depth of the water raises the level of the load on the inspiration muscles. Furthermore, as the lung inspiration and expiration need to be realized according to stroke movements, another different respiration training is also needed (Mitch et al. 2011). UWR players realize their respiration against water resistance, besides they make hyperventilation for fast and swift recovery after holding their breath, and thus their inspiration muscles work harder. Another possible cause may be the used snorkel. Throwing water in the snorkel with a powerful expiration before respiration during emerge causes the expiration muscles to work harder. As there exists more $\mathrm{CO}_{2}$ rate in the air of the snorkel, when the respiration realized from the snorkel, ventilation arises more often (Delapille et al. 2002). The arguments mentioned above may possibly be the reason for the highness of respiration parameters.

\section{Wingate and Vertical Jumping Test}

Results of the Wingate test, which is well-known for its reliability and validity to determine anaerobic strength, show that athletes' average strength was $623.4 \pm 61.2$ watt, peak strength was $900.4 \pm 941$ watt, hearth rate after test was $173.9 \pm 8.8 \mathrm{beat} / \mathrm{min}$. and vertical jumping test values as a result of vertical jump test were $56.5 \pm 6,2 \mathrm{~cm}$. In his study, Platanou (2005) found vertical jumping values of water polo players to be $49.6 \pm 6.5 \mathrm{~cm}$. Aziz et al (2002) determined peak strengths of Singapore National water polo players with the Wingate test as $1048 \pm 167.6$ watt, and Alemdar (2007), in his study, determined average strengths and peak strengths of swimmers with Wingate test, respectively as $639.4 \pm 16.6$ watt and $801.1 \pm 23.6$ watt; and average strengths and peak strengths of swimmers with flippers, respectively as $671.9 \pm 51.5$ watt, and $828.6 \pm 51.8$ watt. Average peak strength of Turkish UWR players as the result of Wingate test was found to be higher than those of Turkish swimmers and monofin swimmers but lower than those of Singapore National water polo players (Alemdar, 2007, Aziz et al. 2002). These results show that the anaerobic strength of Turkish athletes was lower compared to other countries.

\section{Aerobic Capacity Test}

$\mathrm{VO}_{2 \max }$ values of athletes were $52.7 \pm 9.4 \mathrm{ml} / \mathrm{kg} / \mathrm{min}$. and heart rate after test was $182.9 \pm 7.7$ beat/min. Tsekouras et al. (2005) found $\mathrm{VO}_{2 \max }$ values of Greece water polo players as $57.9 \pm 7$ $\mathrm{ml} / \mathrm{kg} / \mathrm{min}$ after $400 \mathrm{~m}$ swim, and heart rate after test as $174 \pm 6$ beat $/ \mathrm{min}$. Frenkl et al (2001) determined $\mathrm{VO}_{2 \max }$ values of water polo players at elite level in their study in Hungary carried out with athletes of various branches with the treadmill as $59.7 \pm 4.9 \mathrm{ml} / \mathrm{kg} / \mathrm{min}$, and heart rate after test as $185.05 \pm 5.4$ beat $/ \mathrm{min}$. Rodriguez (1997) found $\mathrm{VO}_{2 \max }$ values of swimmers and water polo players on bicycle ergo meter as $57.5 \mathrm{ml} / \mathrm{kg} / \mathrm{min}$, heart rate after test as $188.7 \mathrm{beat} / \mathrm{min}$. 
Ates, O., Cavas, L., Sagiroglu, İ., Gencoglu, C, \& Bediz, C. S. (2017). Evaluation of physical and physiological parameters of the elite underwater rugby players. Journal of Human Sciences, 14(4), 3940-3950. doi: $10.14687 /$ ihs.v14i4.4728

In this study, according to ACSM classification, $\mathrm{VO}_{2 \max }$ values of UWR players were found to be quite good; however the value was lower when compared to other studies. This is probably because of the branch differences of training conditions of the players.

\section{Pool Tests}

$50 \mathrm{~m}$ crawl style with $\mathrm{ABC}$ equipment values and heart rate speed of the athletes were $26.5 \pm 2 \mathrm{sec}$, 177.2 $\pm 14.5 \mathrm{beat} / \mathrm{min}, 50 \mathrm{~m}$ apnea values and heart rate averages were $28.1 \pm 2.3 \mathrm{sec}$ and $164.6 \pm 9.1$ beat/min. At the same time, $8 \times 25 \mathrm{~m}$ apnea values, heart rate and lactate value averages were found, respectively as $3.6 \pm 0.4 \mathrm{~min}, 170.4 \pm 9.2 \mathrm{beat} / \mathrm{min}, 12 \pm 2.3 \mathrm{mmol}$, and $400 \mathrm{~m}$ meters crawl style with $\mathrm{ABC}$ equipment values and heart rate averages as $5.5 \pm 0.7 \mathrm{~min}$ and $172.3 \pm 7.6 / \mathrm{min}$. This study bears a distinguishing character as being one of the first studies on underwater rugby players and as evaluating their physical and physiological measurements. We were unable to compare the physical and physiological measurements of the athletes with those of other athletes from the same branch; however with the aim of getting a general idea about the athletes, we evaluated some of the results of this study with the data of swimmers and water polo players.

In conclusion, we can say that as a result of this study the physical and physiological features of underwater rugby branch were determined. The results are open and suitable for testing by carrying on more experiments, applying different test methods or replicating the experiments. With the help of the physical and physiological tests carried out in this study, coaches and trainers can determine the conditions of their athletes and this may help them in preparing their training schedule. With the regularly applied valid tests, it can also be determined and checked whether the designed training schedule leads to increase in physical performance of the players or not. In addition, the athletes can be informed about their performance.

\section{References}

Svantesson U, Zander M, Klingberg S, Slinde F. (2008). Body composition in male elite athletes, comparison of bioelectrical impedance spectroscopy with dual energy X-ray absorptiometry. J Negat Results Biomed, 7 (1).

Aleksandrovic M, Naumovski A, Radovanovic D, Georgiev G. (2007). The influence of basic motor abilities and anthropometric measures on the spesicif motor skills of talented water polo players. Facta Universitatis, Phys Educ Sport, 5(1): 65-74.

Alemdar O. (2007). Comparison of physical and physiological parameters of the elite turkish swimming playerr. Marmara University, Health Sciences Institute, Master Thesis in Turkish

Andreoli A, Melchiorri G, Volpe SL, Sardella F, Iacopino L, De Lorenzo A. (2004). Multicompartment model to assess body composition in professional water polo players. $\mathrm{J}$ Sports Med Phys Fitness,44(1):38-43.

Aziz RA, Lee CH, Teh CK. (2002). Physiological characteristics of singapore national water polo players. J Sports Med Phys Fitness, (42): 315-319.

Cakici CK. (2006). Investigation of the Body Compositions among Turkish 1st Water Polo League Players. Ankara University, Health Sciences Institute, Master Thesis in Turkish

Cavas L., Daglioglu, O., Hazar, M., Gurler, S., Cavas, B., Yurdakoc, K., (2004). A Comparative study: Skinfolds, estimated percentage body fat, total body fat weight and fat-free body mass in the female and male turkish athletes, 13th Balkan Sports Medicine Congress, April 29-May 2, Drama, Greece.

CMAS Underwater Rugby Game Rules, retrieval date: http://www.cmas.org/underwaterrugby/documents-of-the-rugby-commission 
Ates, O., Cavas, L., Sagiroglu, İ., Gencoglu, C, \& Bediz, C. S. (2017). Evaluation of physical and physiological parameters of the elite underwater rugby players. Journal of Human Sciences, 14(4), 3940-3950. doi: $10.14687 /$ ihs.v14i4.4728

Dahjio Y, Noubiap JJ, Azabji-Kenfack M, Essouma M, Loni GE, Onana AE, Dehayem M, Mvom A, Tadjore MN, Sobngwi E. (2016). Impact of a 12-week aerobic exercise training program on anthropometric and metabolic parameters of a group of type 2 diabetes Cameroonian women aged $\geq 50$ years. Ann Transl Med, 4(19):364-369.

Delapille P, Verin E, Chollet TC, Pasquis P. (2002). Heart rate variation after breath hold diving with different underwater swimming velocities. J Sports Med Phys Fitness, (42)1: 79-82.

Frenkl R, Meszaros J, Soliman AY, Mohacsi J.(2001). Body composition and peak aerobic power in male international level hungarian athletes. Acta Physiol Hung, 88 (3-4): 251-258.

Koç H. (2006). Comparement of some physical and physiological parameters of football players and tennis players. Health Sciences Journal, 15(3): 161-167.

Lozovina V, Pavicic L. (2004). Antropometric changes in elite male water polo players:Survey in 1980 and 1995. Croatian Med J, 45(2): 202-205.

Melchiorri G, Padua E, Sardella F, Manzi V, Tancredi V, Bonifazi M. (2010);Physiological profile of water polo players in different competitive levels. J Sports Med Phys Fitness, 50:19-24

Mitch L, Sophie C. (2011). Inspiratory muscle fatigue significantly affects breating frequency, stroke rate and stroke length during 200-m front-crawl swimming. Journal of Strength and Conditioning Research. 25(10):2691-2695

Nekooei P, Majlesi S, Sharifi G, Kamalden TFT, Nekooei P. (2016). Comparison of anthropometric parameters among iranian and spanish water polo players. Russian Open Medical Journal, 5 (2).

Nogueira FDS, Pompeu FAMS. (2006). Maximal workload prediction models in the clinical cardiopulmonary effort test. Arquivos Brasileiros de Cardiologia. 2(87).

Ongun A, Kurt C, Kurt İ. (2006). Genç milli Türk su topu oyuncularının vücut kompozisyonu ve bazı antropometrik fizyolojik değerleri. 9. Uluslararası Spor Bilimleri Kongresi.

Ostojic MS. (2000). Physical and physiological characteristics of elite serbian soccer players. Facta Universitatis, Phys Educ Sport, 1(7): 23-29.

Platanou T. (2005) On-water and dryland vertical jump in water polo players. J Sports Med Phys Fitness, 45:26-31

Rodriguez AF. (1997). Metabolic evaluation of swimmers and water polo players. Kinesiology; 2(1): 19-29.

Sogut M, Muniroglu RS, Deliceoglu, G. (2004). Investigation of anthropometric and somatotype characteristics of junior male tennis players in different categories. Spormetre, 2 (4): 155162.

Tsekous EY, Kavouras AS, Campagna A, Kotsis PY. (2005). The antropometrical and physiological characteristics of elite water polo players. Eur J Appl Physiol, (95): 35-41.

Turan T. (1989). .Investigation of the physical and physiological profiles of the elite waterpolo players. Marmara University, Health Sciences Institute, Master Thesis in Turkish

World Underwater Federation (CMAS). [cited 2017 May 22]. Available from: http://www.cmas.org Wylegala JA, Pendergast DR, Gosselin LE, Warkander DE, Lundgren CEG. (2007). Prespiratory muscle training impoves swimming endurance in divers. Eur J Appl Physiol. (99):393-404 